\title{
A Thematic Analysis of Graffiti on the University Classroom Walls - A Case of Iran
}

\author{
Maryam Farnia \\ Assistant Professor, Department of Foreign Languages and Linguistics, Payame Noor University, Iran \\ E-mail: mfarniair@gmail.com
}

Received: 23-12-2013

Accepted: 25-01-2014

Published: 01-05-2014

doi:10.7575/aiac.ijalel.v.3n.3p.48

URL: http://dx.doi.org/10.7575/aiac.ijalel.v.3n.3p.48

\begin{abstract}
The present study positions a research to analyze the university students' graffiti on classroom walls to make a thematic analysis of the graffiti used in the Iranian higher education context. It is an attempt to investigate how university students voice their opinions and express themselves using graffiti on the university classroom walls. The study is based on the documentation and classification of more than 200 pieces of graffiti on university classroom walls in Isfahan, Iran. The analysis suggests different themes such as love and hatred, politics, religion, poem, class notes, signature, presence, date, complaint/despair, self-expression, drawings, etc. It is believed that this study is not only a sociological analysis of graffiti in the university context, but it may also be interesting to a wider audience like educators, administrators, teachers and parents.
\end{abstract}

Keywords: graffiti, classroom walls, thematic analysis, Iranian university students, culture

\section{Introduction}

One might wonder what motivates people to make graffiti or "little scratching" (Bartholome and Snyder, 2004) on walls or surfaces they pass by and what inspired them to scratch things on the walls they might never share with family members or friends. Graffiti could be regarded as "freedom of expression" (Tracy, 2005, p.22) whose writer is often anonymous and is normally restrained by personal inhibitions and social norms to freely express himself/herself (Abel and Buckley, 1977). From this aspect, graffiti could be viewed as a second diary book (Raymonda, 2008) which represents the voice of people, in either public or private places, to convey their anger, instantaneous thought, love declaration, political proclamation, outcry, etc. As a result, "the analysis of graffiti could provide vital information for investigations of the breakdown of discipline and order, or into the workings of the moronic or ego-starved or bored mind" (Reisner, 1974, p.8).

Although graffiti has been an important cultural phenomenon for many years and it has received so many studies throughout its history, there is still room to explore how graffiti in different contexts serve to voice their authors' opinions. The present paper positions a thematic qualitative analytical research on the graffiti found on a university classroom walls in Esfahan, Iran. The study is to explore how student use inscriptions to express themselves in the Iranian higher education context.

\section{Review of the literature}

The word graffiti originated from the Greek word graphein (to write) (Reisen, 1971), and it is the plural form of the Italian word graffito to mean drawing and inscription. As Blume (1987) put it, "[graffiti is any] pictorial or written inscription for which no official provision is made and which is largely unwanted, and which are written on the most various publicly accessible surfaces, normally by anonymous individuals (but sometimes by groups)" (p.137). As Abel and Buckley (1977) put it:

"Graffiti is a form of communication that is both personal and free of the everyday social strains that normally prevent people from giving uninhibited reign to their thoughts. As such, these sometimes crude inscriptions offer some intriguing insights into the people who author them and into the society in which these people belong" (p.3)

Graffiti in English originally refers to certain painting techniques of mural painting; however, nowadays it is associated with any types of scratches, drawings, paintings, symbols, signs on walls, or anywhere regardless of what motivates the writing (Basthomi, 2007). In the past, different types of graffiti (i.e. sgraffito, graffito pottery) were regarded as status of art. According to Plesch (2002), inscriptions observed on the bodies of holy figures inside the churches in Italy and elsewhere were regarded as a devotional act despite signs forbidding the pilgrims to do so. In such sacred places, leaving graffiti by pilgrims was a means to record their desire to visit and maintain a presence: "to write one's name somewhere in a sacred place leaves a presence, one that outlasts the brevity of a life, indeed 'forever"' (Dupront, 1987, in Plesch, 2002, p.133).

The variations of graffiti types made some researchers to identify them in different categories. Gadsby (1995) classified graffiti into six main categories: latrinalia, public, tags, historical, folk epigraphy, and humorous. Latrinalia, a term used 
by Dundes (1966) to refer to graffiti found in toilets (Gadsby, 1995) has been received extensive research studies (e.g. Cole, 1991; Nwoye, 1993; Finders, 1997; Mueller, 2000; Trahan, 2011). Although regarded as the dirtiest place, they are believed to be the most widely exposed area in most places. As Haslim (2012) maintained, "Public bathrooms are ideal hothouses and are associated with activities that make taboo ideas and images highlight salient" (p. 15). Public graffiti, on the other hand, include graffiti written on public spaces and sites (i.e. walls of building, trains, or buses). Tags are unique representation of individuals and they often employ writers' specific characteristics such as names, initial, address, etc. As Reisner (1971) pointed out:

"As the graffiti writer gets more and more into these open areas where his chances of being seen are greater, there is a tendency for his message to be of a generalized nature without too much pornographic emphasis....in lavatories, or in any place where there is complete privacy, however, the messages, although still often banal, are much more visceral" (Reisner, 1971, p.4)

Historical graffiti are the ones which are studied long after they were created and hence, their studies are only possible through the historical archives (Gadsby,1995) and it is a type of graffiti that except for a few selected examples has received few research studies (Forster, Vettese-Forster, and Borland, 2012). Some examples of historical graffiti are the studies of wall graffiti at Pompeii (Lindsay, 1960; Tanzer, 1939) and the recent investigation of historical building sites in Scotlland (Foster, et al, 2012).

Folk epigraphy is a type of graffiti craved by common people on walls, woods, etc. An example of folk epigraphy is the graffiti craved by people in Pompeii into the walls (Lindsay, 1960). Read (1935) conducted another study in his trip to the West where he recorded and observed a great number of graffiti on the walls of public washrooms. Read (1935) stated that, "It was borne upon me that these inscriptions are a form of folk-lore that should be made the subject of scholarly studies" (p.17). This graffiti type is, however, about to vanish due to the rise of sprays and markers which make writing graffiti easier and faster (Gadsby, 1995).

Humorous graffiti is any type of graffiti created for the purpose of entertainment (Gadsby, 1995). Some researchers (e.g. Bech, 1982; Warakomski, 1991) examined this type of graffiti linguistically in order to find what motivated their writers.

In the modern era, graffiti received a different outlook, largely viewed as damage to public or private property and an illegal action rather than an artistic technique. Graffiti is viewed also a source of data that includes linguistic studies of discourse patterns and grammar, an investigation of cultural production in different areas and an examination of gender differences. Studies on graffiti in different areas have shown that the aim and types of messages conveyed through graffiti vary cross-culturally. In his study of urban graffiti, Hanauer (2004) considered graffiti as a specific communicative act used by a variety of subcultures to provide personal voices in the public domain. Accordingly,

"graffiti fulfills three functions of (a) allowing the entry within public discourse of messages regarded as marginal by other media; (b) providing the individual with the opportunity to express controversial contents publicly; and finally (c) it offers marginal groups the possibility of expressing themselves publicly" (p.29).

Based on Hanauer's definition, graffiti plays an important role since it acts as a very powerful mode of expression for groups that essentially feel disenfranchised by the wider society. Pietrosanti (2010) indicated that "political groups use graffiti as a communication tool. Major themes for political graffiti are associated with labor conditions, freedom, political power, unemployment, religious thought, and civil rights" (p.2). It is not surprising that graffiti research from the 1960s onward was used to mirror political upheaval, civil rights movements and anti-war protests (Welsh, 1993). An example of challenging the authority through graffiti can be found in Iran before the 1979 revolution, where it appeared in the form of political commentary and it was used as a medium to communicate people's anger and objection to the regime. Hence, the graffiti writers were prosecuted. However, in some areas, a closer examination of the wall graffiti will present graffiti as an avenue through which "a minority group, denying other legitimate media, articulate pent up social and political concerns" (Nwyo, 1993). For instance, as Kan (2006) stated, students in Kenya used graffiti as "an alternative medium of communication" to express themselves where they have no opportunities in the decisions made for them. In Ghana, it is reported that, "graffiti is a rallying force for dissonant political and social communication since the sociocultural and the political atmosphere do not warrant protest discourse" (Obeng, 2000, p.338). It also takes a form of gender-based communication because only male students use it (ibid).

Studies on graffiti have appealed to so many researchers' interest for the last decades. Graffiti is viewed as a source of data that includes linguistic studies of discourse patterns and grammar, investigation of cultural production in different areas. Hanauer (2004, p.29) indicated that graffiti, within the scope of linguistics, has been investigated as a mode of linguistic communication within a community setting in order to understand the discourse resources present and their ramifications within a particular community setting. Some studies investigated the effect of sex differences in writing graffiti (e.g. Arluke, Kuakoff and Levin, 1987; McMenemy and Cornish, 1993; Teixeira and Otta, 1998; Teixeira, Otta, and Siqueira, 2003; Green, 2003; Matthews, Speers, and Ball, 2012; Haslem, 2012). In a study of graffiti at the University of Otago's central library, Green (2003) analyzed inscriptions collected from males' and females' toilets and study booths. His findings indicated that men and women's topic choice and language style were different. In terms of topic, men' graffiti were concerned more with homosexuality and political contents whereas women mostly used topics having to do with sex, relationships, religion and philosophy. In terms of language style, the analysis concluded men used a negative and argumentative discourse while women showed more of a positive and supportive one. No gender 
differences were found in the inscriptions regarding exams/studying, sport, music or humorous contents. Cole (1991) conducted a graffiti research that dealt with female graffiti at lavatory stalls at the University of Illinois. In his study, graffiti were found to be an alternative means of expression for women whose participation was found to be similar to consciousness-raising groups. This study came up with the findings that women saw the washroom stalls as a place to vent anger as well as a place to solicit and receive advice, support and consolation; and express their dissatisfaction.

Likewise, Otta (1993) gathered data from men and women's restrooms in ten university buildings in Brazil during the 1990s. The goal was to examine the effect of gender differences in writing graffiti. Therefore, the question under study and the methodology guiding data collection were similar to previous studies which were interested in gender. Using a thematic approach, graffiti were classified into thematic categories such as racial, sexual or general insults. The major finding was that there was a gender difference in graffiti both in quantity and content. For example, more graffiti writings were found in men's restrooms than those found in women's restrooms. In terms of content, results indicated that men's restrooms included different thematic types of graffiti where most of them were concerned with sexuality and politics. Otta (1993) concluded that women's graffiti were more conservative and conventional than men's graffiti due to the fact that certain types of graffiti were not recorded.

Another line of research was intended to study the contents and the underlying reasons for graffiti written by prospective teachers. In their study, Şad and Kutlu (2009) utilized a content method analysis and interviews to understand the reasons behind graffiti writing. The results highlighted the significance of bathroom graffiti writing as a medium for students and teachers to express themselves in terms of sexual, political, and religious issues and to socialize through proper communication with others. In terms of graffiti content, the data were analyzed into two types comprising both socially acceptable topics and anonymous inscriptions. Accordingly, socially acceptable topics were concerned with belongingness, homesickness, romance, and humor or the form of someone's name and signs (doodling). Topics such as sex and politics or religion were studied under anonymous inscriptions which were found to be the production of men rather than women.

Studies attributed to justify and understand the motives behind wall writings reported various reasons for why the younger generation becomes involved in graffiti. In her study, Taylor (2012) argued that boredom, peer emulation, aggression, identity formation, retaliations may lead early adolescents (12-14 years old), mid-late adolescents (15-17 years old) and adults to be involved in graffiti writing. However, it was found that factors such as addiction to risk, recognition, and respect that the graffiti life-style provides would affect all graffiti-writing age groups.

Following a sociolinguistic approach, Raymonda (2008) investigated the graffiti arts in Surakarta, Indonesia, in terms of register, meaning and function of graffiti art pictures. He provided an analysis of the purpose of graffiti writers within the style of writing. An important contribution of that study was that it expanded the research of graffiti arts. However, that study limited its analysis to register by utilizing one sociolinguistics method, i.e. interview in collecting the data to know the social background of informers. By doing so, the study might not be valid and sufficient since it failed to provide a deep insight to graffiti arts and graffiti writers' community located in Surakarta.

In her study, Kan (2006) investigated graffiti writing by students in secondary schools in Kenya. The goal was to identify graffiti, describe their stylistic features, discover the messages they put across and establish different attitudes towards graffiti. However, the research was based on Leech's Model of Stylistic Analysis and Critical Discourse Analysis but limited to a sociolinguistic approach to the study of graffiti in secondary schools. Texts were collected in ten secondary schools in the Nyandarua district. Out of two hundred texts, twenty from each school, were purposively sampled for analysis. The author also interviewed two teachers and five students from each school. Results indicated that graffiti was used as a medium to communicate opinions on different topics like love and sex, school authority, student welfare, religion and politics. One of the major contributions of this study was that it can be used as a guide to secondary school policy-makers, administrators and teachers who will provide a better understanding of the meaning of graffiti and thus understand their students accordingly.

In a comparative study of public and private graffiti, Koon- Hwee (2001) divided graffiti into two major types: doodling and latrinalia vs. gang, tags and pieces. His findings were based on 50 survey forms collected from anonymous adolescents in a small Midwestern community in the United States. The researcher used teenage psychology to interpret adolescents' involvement in both private and public graffiti. The analysis showed respondents' involvement in some form of graffiti, particularly when they felt bored or stressed out in school. Moreover, most young graffiti writers did not differentiate between graffiti art and vandalism. According to Koon-Hwee (2001), it would be hard to control the desire of young adolescents in graffiti writing as they would be more attracted to such activities since society pronounced it illegal. Therefore, the author suggested that graffiti should be considered as an element in the educational system and as a part of the secondary school art curriculum and instruction.

Peteet (1996) investigated graffiti writing in the Occupied West Bank in Palestine during the late 1980's and early 1990's where he examined graffiti as a form of cultural production. Writing on the walls embraced some of the cultural graffiti (shi'arat) which suggested that forms of cultural productions are deployed as a means of resistance. In this study, graffiti is not only used as a means of communication, but they were an intervention in a relationship of power. Peteet (1996) mentioned that, "As cultural artifacts, graffiti were a critical component of a complex and diffuse attempt to overthrow hierarchy; they were Palestinian voices, archival and interventionist" (p.140). Thus, graffiti becomes a cultural production where it "affirmed community and resistance, debated tradition, indexed historical events and processes, and inscribed memory" (p.141). 
Among graffiti studies which are connected to educational contexts is Ball's (2004). Ball (2004) examined the values/concerns of today's college students in the US as expressed through desktop graffiti. Data were collected from random samples of nine classrooms in two buildings on a major university campus in the United States. The graffiti from each room were analyzed qualitatively and quantitatively. A total of 1,758 pieces of graffiti were examined, and based on the content of the inscriptions they were classified into categories such as alcohol, cars, curse words, depression, drugs, Greek life, love messages, etc. In terms of content, as Ball (2004) stated, graffiti with the theme of university and sexual content were the most frequently used types of graffiti on the desktops. An examination of the graffiti on the venues based on the courses being taught there, the findings show that in the room where English was the predominating course taught, sex was the most popular graffiti topic suggesting this assumption that the course type can contribute to a specific type of graffiti.

Building upon the results of previous studies conducted on graffiti in bathrooms and public areas, Dombrowski (2011) documented and classified graffiti in the main library of four universities in the United States: the University of Chicago, Brown University, the University of Colorado at Boulder, and Arizona State University. Dombrowski conducted a thematic analysis based on 1346 pieces of graffiti. The inscriptions were then classified into a number of categories such as advice, classes, despair, drugs, etc. The findings show that the three universities were different in terms of the use and contents of graffiti. Moreover, graffiti with the theme of insults and remarks about advice, classes, love, the surroundings, school, and oneself were the most typical topics of graffiti found in university libraries in addition to sex.

Studies on graffiti have been appealed to many disciplines such as linguistics, cultural studies, history, psychology, art and communication (Pietrosanti, 2010). There are extensive amount of contemporary research on graffiti; however, there are few studies investigating graffiti on classroom walls in higher education environments. In Iran, like other places in the world, graffiti is viewed as vandalism to personal and public property. Walking in towns, a visitor may find inscriptions anywhere, e.g. buses, trains, on the walls in washroom stalls, buildings, and even bank notes. The most painful ones are the tags visitors make on the walls of historical buildings. The municipalities take some action to avoid more damage to the walls or to keep the surfaces clean by putting some glass shields between the walls and visitors to avoid direct touch in old historical buildings and cover the walls with ceramic tiles. Despite all these protections, there are still some places which remained unprotected against the damages made by graffiti, including university classroom walls.

This study addresses this issue by making a thematic analysis of the inscriptions on university classroom walls at a university in Esfahan, Iran. It is believed that students lack the opportunity to have their opinions heard since they are seen at as a powerless group within the classroom setting and their graffiti and according to Nwoye (1993), graffiti on university campuses are almost alike across the world, which proved the fact that the student population is a minority in terms of self-expression. They have not received adequate attention in their attempts to articulate their views when mainstream society has denied them. Thus, it would be interesting to examine the way they express themselves via graffiti.

\section{Methodology}

Three classes were randomly selected from the Faculty of Humanities in a university in Esfahan, Iran. The faculty offers courses in law, English language teaching, Persian literature, history, etc., the classes of which are held in different corridors. However, the data for the present study were collected from the ones which are used in common among all sections in the faculty. They are co-ed classes and the class capacity is up to 70 students. The graffiti were collected from the classroom walls during winter break 2012. The classroom walls have not been cleaned or painted for more than 5 years. It is difficult to state the required minimum number of the corpus for results of a topical analysis to be significant (Dombrowski, 2011), but for this study more than two hundred pieces of graffiti were collected and analyzed using the content analysis approach. The inscriptions were photographed by the researchers and then transcribed for further analysis. After an examination, the following categories were decided upon and used to classify the graffiti: love and hatred, politics, religion, important dates in a person's life, signature, drawings, poetry, selfexpression, complaint/despair, etc.

\section{Analysis}

A description of the nature of various themes and subjects found through a content analysis of the wall graffiti is presented in this section. Two hundred pieces of graffiti were collected from three classrooms, many of which were indiscernible and have thus been dropped from further analysis. The qualitative analysis of the graffiti has given the following categories:

\subsection{Expressions of love and hatred}

Love themes were depicted in different ways including explicit words in either Farsi or English or sketches of a heart with names on it, which symbolize love. The most common expressions found on university walls were the English words "I love X" or the Farsi words "X دوستت دارم" (Doostet daram X, I love you X) where X is first name or last name of a male or female; however, in our study, the $\mathrm{X}$ was commonly replaced by male's name. In other words, it can be inferred that most love expressions were written by female students. There were also few examples in which $\mathrm{X}$ was replaced by a family name for which the sex of the $\mathrm{X}$ is not clear. Some expressions of hatred were also found among the graffiti. The expression of hatred written in English language begin with I hate you X where X is a person's name. In graffiti samples of this study, $\mathrm{X}$ replaced a male's name. 


\section{Examples:}

- دوستت دارم ردايى(I love you Redaei)

- I love you Kamyar

- I would like to be with you.

- I hate you Hamid.

\subsection{Politics}

There were few graffiti whose writers wish unflinching and permanent status and life of the Islamic revolution and the Supreme Leader. In the data of the present study, no graffiti with the content of anti-state authority was found.

Examples:

- نثار امام و شهدا صلوت -

- Say blessings for the Imam (the late Imam Khomeini was the first Islamic republic leader after the revolution) and the martyrs (martyrs refers to those martyred during the war between Iran and Iraq)

ياد امام و شهدا زنده و جاويد باد

- The remembrance of Imam and the martyrs is perennial and immortal.

\subsection{Presence}

Besides love themes, themes depicting one's presence can be frequently found among public graffiti, not to mention the university context. The graffiti writers expressed their presence in the context using a statement followed by the name of the lecture they attended, or writing X or several X's where X is the name of a person, or writing Farsi words “ X از "يادكارى" (memento from X) where X is usually the name of the graffiti writer. This type of graffiti is often accompanied by the other type of graffiti named date.

Examples:

- مهرداد(Mehrdad)

-Iman- Jafar

- يادكارى از على (a memento from Ali)

- Noushin

برق 85، فنى 1 -

The last graffiti example indicates that the graffiti writer was a student of electronics who attended university in 1385 and his faculty is located at engineering building 1.

\subsection{Date}

The graffiti writers often record a date assumed to be the date the graffiti is written on the walls. This type of graffiti sometimes followed another graffiti type, e.g. presence, signature, self-expression etc. The dates are often shown by day, month and year in the Iranian calendar and a few in the Christian calendar. Based on the Iranian calendar, some dates are as old as 8 years. According to the Iranian calendar, at the time of writing this paper it is the year 1392 . The second and fourth graffiti below are examples of date and presence.

Examples:

$-87 / 12 / 19$

-14/2/1388 فخر الدين (Fakhrodin, a male name)

$-1390 / 8 / 10$

شنبه ساعت 11.40 دقيقه دانشجوى رشته مهندسى كاميبوتر سخت افزار (signature)

(Saturday, 11.40, student of computer hardware engineering )

\subsection{Religion}

Religion is a concept which is intertwined with many people's beliefs and life in Iran. This concept has not even been imparted in writing graffiti. Graffiti under the category of religion include verses from the Quran in Arabic (language of the Holy Book and daily prayers), salutations to Prophet Mohammad or help requests to Shiite religious imams (i.e. Prophet Successor). The graffiti with religious contents were as follows:

Examples:

- O' Ali ( Imam Ali is the first Shiite leader and Prophet Mohammad's son-in-law)

- O' Hossein (Imam Hossein is the third Shiite successor, Son of Imam Ali and Prophet Mohammad's offspring. His reputation in Shiite is for the martyrdom of Iman Hossein and his 72 soldiers and family in a desert in Karbala, present Iraq by Omavi Dynasty. Shiites commemorate and mourn this event every year in Muharram.

-O’ Zahra (Prophet's daughter, Imam Ali’s wife, Imam Hossein's mother). 


\subsection{Signature}

Signatures signify one's authority or presence. Among the graffiti found on the walls were some forms of signature typically used in Iran (i.e. some forms of intricate curved drawings) or in non-common forms, (i.e. wirings one's name in English). This category can be regarded as one's presence in the place. The signatures either appeared at the end of a short note or independently (e.g. lecture X).

\subsection{Drawings}

Some graffiti in the form of drawings were recorded. The drawings depict tearing eyes, hearts, broken hearts or the ones departed by an arrow. No names or signatures around these sketches identified the gender of the graffiti writers.

\subsection{Class Notes}

Some graffiti were found in the form of class notes written in crooked lines on the walls. The class notes were in the form of math equations or formulas, outlines or extracts from books. They were presumably written for later use during exam times.

\subsection{Poetry}

Poems could be found on walls with the love, hatred, complaint and missing home (town) contents. The source of the poems was quite diverse. They ranged from songs' lyrics to hemistiches of famous Iranian poems. The graffiti of this category were all found in Persian.

Examples:

$$
\text { يادم رفت كه بت بحم تو لاله ناز منى يادم رفت تو عاشقى تو......ناز منى }
$$

(I forgot to tell you that you're cute tulips I forgot you're cute ...... love you)

$$
\text { بى نو هر لحظه مر ا بيم فرو ريختن است }
$$

(Without you I am afraid of collapsing every time)

\subsection{Self-expression}

Self-expression appears in different forms. This classification includes those personal statements about the physical or emotional state of the writer. This classification includes expressions about happiness, joy, despair, past memories, etc.

$$
\text { من خسته شدم كى كلاس تموم ميشه - مئ }
$$

(I feel tired. When does the class end?).

- Please forgive me

- The world is so shining without you.

\subsection{Despair/Complaint}

Students always have something to complain about during their study. Their dissatisfaction can partly be related their educational context, i.e. their university, or their major. The topic of graffiti under the classification of despair/complaint includes statement about lectures, lecturers, textbook or time of the lecture. Some also express their despair about the university they attended .

Examples:

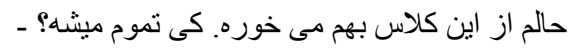

I feel sick of this class. When is it going to end?

انشاا.. بعد از اين ترم بار رفنن من به تهران مو افقت شود. -

I hope the university agrees with my request to move to Tehran for the next semester.

\subsection{Mobile and Phone numbers}

This classification includes those graffiti words about different type of mobile devices. Nokia, Sony Ericson, Sumsung, and other types of mobile brands are among the graffiti on the walls. In addition, some graffiti in the form of contact numbers could stand for the writer's request for friendship or revenge from an ex-friend.

\subsection{Abstract words}

Among the corpora, there were some single abstract words which could not be classified under other categories (e.g. endurance, strength).

\subsection{Scribble}

There were some graffiti which were unclear scribble, the number of which were not that much compared to other types of graffiti. They could not be classified either under signature or drawings of clear objects.

\section{Discussion}

Despite the fact that the digital world provides an avenue on which people can express their thoughts freely and without any limit (e.g. twitter, Facebook), people still persist on writing on the walls (Matthews, Speers and Ball, 2012). According to Stocker, Dutcher, Hargrove and Cook (1972), graffiti are viewed as a reflection of the attitude of a given community. The findings of this paper are a good example of this assumption. In Iran, a country in which religion is intertwined and twisted with the majority of people's minds and souls, it is not surprising to find graffiti with religious 
contents on the walls. Those special pieces of graffiti with religious themes have also been the mark of Shiite Muslims. In everyday life, these expressions are used to beseech some divine sources for help. The religious names found in the data are the name of Zahra (the daughter of Prophet Muhammad) and the Prophet's Household. Graffiti with diverse religious contents have also been found in other types of graffiti such as truck graffiti in Iran (Farni and Tohidian, 2013). The graffiti on the trucks though have various religious contents such as references to God, references to Prophet and his Household, lines from the Quran and prayers in Arabic.

This indicates that although the language of correspondence is Farsi, and Arabic is only used for religious purposes (except for the loanwords), the Arabic language is frequently used in the form of religious prayers. The use of Arabic can be explained by the fact that it is the language of the Holy Book, thus using the exact word would make them feel closer to God and that spiritually connected to Him. Arabic is the language of Quran and all Muslims around the world try to be able to read the language for religious purposes. Daily prayers are also said in Arabic.

Graffiti with love and hatred is a common theme in many other studies on graffiti. Love themes have always been an integral topic of graffiti on walls anywhere let alone the university classroom walls. The pattern of the love expression "I love X" is similar to the pattern found in Dombrowski's (2011) wall graffiti of the universities in the United States and Ball's (2004) study of desktop graffiti at the colleges in the United States. The graffiti writers in the present study, however, used both Farsi (the formal language in Iran) and English to express their love and hatred. The pattern of expressing hatred is "I hate $X$ " where $\mathrm{X}$ is the person who is being hated.

Similar is the case for graffiti that included poems and quotes that express love, emotions and feelings to someone. The popularity of quotes across the corpora comes from lyrics from songs or literature. They were either phrases from a famous Persian song or lines from Persian poems, the theme of which has mostly been love, hatred, abandonment, and loss of the beloved. An explanation for such graffiti with both love and hatred or romantic contents in general is in line with the fact that students might not be able to find people to listen to them in terms of their emotions and relationships. Beside, discussion of such themes with teachers might not be permitted, thus students would express themselves by writing on the walls. In their study, Klingman, Shalev, and Peariman (2000) argued that when the younger generation finds people with whom to talk, they still might hesitate to express themselves with these individuals and choose graffiti as a form of reflecting strongly felt internal experiences and emotions safely. In this sense, graffiti is seen at as a means of counseling someone's feelings and emotions. It might be the case of our participants, however, ongoing research on graffiti writing and its psychological effects would give more insight into this concern.

Although politics has been the main part of most graffiti research conducted at universities, politics were almost absent in the data collected for this study. Despite controversial political debates during the last couple of years from the postpresidential election period in 2009 due to several sanctions imposed on Iran and the ongoing nuclear arguments, one might expect to find graffiti with relation to them. However, graffiti with themes of politics or commentary on governments or authorities were rarely found in the data collected or in other words the graffiti with political contents were not as diverse as other types of graffiti found in this study. There were few pro-government expressions. However, the political contents of the graffiti in Dombrowski's (2011) and Ball's (2004) study contained expressions of people's pro- or anti-government sentiments. One assumption can be that certain types of graffiti have vanished or painted either by university authorities or by pro-government supporters.

Although the production of sexual, insulting, threatening, and racist graffiti have been reported as the theme of many graffiti studies (Schreer and Strichartz, 1997; Ball, 2004, Dombrowski, 2011), it was absent in the present corpora. It should be mentioned that graffiti is observed as the mirror of people's attitude of a given community. In other words, Stocker et al. (1972) viewed graffiti as an accurate indicator of the social attitudes of a community. In Iranian culture, the absent graffiti (i.e. sexual expressions, insult, etc.) are regarded as taboo and are sanctioned and restricted on institutional and individual levels in Iran. Not only they are culturally abandoned but also religious rules do not allow the use of such sexual expressions, insults, etc. Although the present corpora cannot generalize the absent use of sexual and racism words to all types of graffiti found at university, it can be assumed that they might be at least not produced in places where it is exposed to everyone's sights. Another assumption is that they might be removed when produced on the walls exposed to everyone.

The anonymity of the graffiti writers lets them share information publicly which sometimes has social consequences. According to Gach (1973), graffiti is a means through which "students communicate attitudes and feelings they would hesitate to utter publicly" (p. 285). A student inscribed his male friend's number on a men's restroom which resulted in disturbing the contact owner from several men having sex inquiries (Barnett, 2006). Similar graffiti were found in our corpora where some mobile numbers were found on the walls which had apparently been inscribed there by ex-friends as the message next to the phone refers to a person who broke up a relation.

It is very common to use the same lecture hall or classroom for taking class quizzes and or as final exam venues. This might support the fact that the majority of wall graffiti on university classroom walls are devoted to extracts from university textbooks to be used during exam time. The graffiti written for this purpose were some extracts in the form of outlines of subjects like history, law, literature, some math formulas, or some names or words related to a certain subject matter like history, literature, or law. What made this type of graffiti significant to observers was that they were written in crooked line. It was noticeable that they were written in this way for the easiness of hand moving on the walls. Şad and Kutlu (2009) argued that such type of graffiti are produced by students who do not like studying, whose performance is poor, and who are not committed to education. Thus, students use the walls as a medium for cheating and performing better in exams. 
Graffiti such as presence, signature and date are all connected to the writers' motive to identify himself; as these are used as a furnishing proof of one's existence. Students used graffiti to emphasize their individual sense of being within the collective society. This expresses power, sense of self, seeking recognition and confirming identity. Another explanation for students' graffiti involvement arises out of a fundamental desire to challenge the boredom associated with their rule-bound everyday lives. Taylor (2012) indicated that the younger generation "complains of feeling constrained by adults. A feeling, compounded by the lack of youth unregulated recreational opportunities". In her study of graffti, one teen participant explained, "There's nothing for us to do round my place so going night tagging with my mates, now that's like real fun" (p.57-58).

There were some scratches on the wall in the form of drawing, single abstract word or even unclear scribble. The simplicity of the objects which were often sketched by black pens indicates some meaningful objects which were commonly associated with love failure or broken-up relationship such as tearing eyes, hearts, broken hearts, and hearts pierced by an arrow. An explanation for such scratches on the wall is the fact that students might be bored and not showing interest in the content of a lesson or lecture. Such samples of graffiti are very significant since they provide vital information for the investigation of the educational system within the university's context. More and more activities might be encouraged to engage students into the learning process. Our justification is in line with Sad and Kutlu's (2009) findings as they found that all the inscriptions in classes/labs were written during a lesson because of boredom and lack of interest in the lesson. Examples of their interviewees' opinions are:

"When you become bored during the lesson, you unwittingly inscribe something on the desk. [Interviewee C]... When I became bored as the teacher or one of the classmates was giving a presentation, I wrote a message on the desk since there was no paper... [Interviewee F]" (p.45).

Another type of graffiti that is related to the educational system is complaints or despair. Students express their dissatisfaction of the university, their major or their classes. This is in line with Şad and Kutlu (2009) who argued that, "Graffiti in labs/classes points to the possibility that the faculty's failure to involve the students actively in class causes boredom for students, which implies a need to apply more participative instruction on the part of instructors" (p.40). One example had been recorded in the data where the student wrote his desire to be transferred to another university, complaining about the tedious system of transferring students between universities in Iran. It should be mentioned that student transfer is possible in the Iranian university system under special conditions, the primary of which is that students should study in the same academic institutions (e.g. private, state, non-state universities) and find another student from the target university who is willing to be transferred to the applicant's university.

The scribbles on the wall, though not very clear, could be regarded in different categories. The observers of those graffiti just wonder if the graffiti writers failed to inscribe what they intended due to limited free space on the walls, or they planned to leave a signature but the outcome is just a crooked line on the wall.

Graffiti such as contact number can be an indication of the students' willingness to communicate and be connected with people. Moreover, since university students represent the youth generation, technology such as mobile phones is therefore one of their favorites. It is not surprising then to record graffiti such as Nokia, Sony Ericson, Sumsung, and other types of mobile brands on the walls. This also can be explained under the desire and wish to have a mobile phone and be part of the modern society.

Among the graffiti found on the walls, the most eye-catching and salient ones are the pieces of extracts from the text books. These types of graffiti are longer in length compared to other ones and thus appealed to the viewers' attention. Tags and graffiti with love/hatred contents were the next categories which fascinate the viewers.

\section{Conclusion}

Graffiti could be easily found almost everywhere: on the walls of public buildings, on the seats of public buses and trains, on the back of money notes, on the walls of restrooms at universities, schools, etc. Gender, family, personal and social issues have always been the topic of graffiti, the amount and size of which are sometimes different from place to place. The present paper addresses a thematic analysis of graffiti on the classroom walls at university. The analysis of inscriptions on the university walls has provided interesting insights. The results obtained on the analysis of the graffiti show that students appeal to a variety of theme to express themselves: love and hatred, politics, religion, poetry, academic/classroom materials, signature, presence, date, complaint/despair, self-expression, drawings, etc. This classification, however, is from only one corpora and expanding the number of corpora could have possibly given more confidence about the types and topics of graffiti used in higher education contexts. Graffiti with sexual contents and racism were absent in the data collected for this study.

One of the main themes to emerge from the present study is Iranian graffiti culture. The findings of the present study are vital in understanding how graffiti culture is implemented in Iran within the university's domain. In fact, this study is more likely to be considered as a pioneer attempt that perhaps looks at the foci of Iranian graffiti. Iranian graffiti culture is probably unique in its themes, more particularly the contents of its graffiti themes. In other words, many of the main graffiti themes which were documented through undertaking this study concur with those of previous studies whilst also offering a fresh insight into newer themes to be documented. One feature of Iranian graffiti culture can be seen in the religion theme, where the use of examples and writings are pieces of religious graffiti related to Shiite Muslims. In keeping up with the findings of previous studies, the present study differs in that the production of some common themes, which were predominately presented in the previous studies such as sexual, insult, threat, and racism graffiti (Schreer and Strichartz, 1997; Ball, 2004, Dombrowski, 2011), were absent in the present corpora. Again the 
impact of Iranian culture is on the surface and probably the reason behind the absence of such graffiti themes since these are prohibited not only socially but also religiously.

The present study shares these thematic categories with previous studies conducted within the same context. Several studies come up with several names and themes, however, some were over presented while others were poorly presented or even were absent. Accordingly, themes such as love and hatred, politics, religion, poem, complaint/despair, self-expression probably were the most commonly categorized example documented in perhaps almost all the studies. Yet, political themes were almost absent in the data collected for this study.

The findings of the research can contribute to the body of research in discourse studies and sociolinguistics by giving an analysis of language us se in society. There are several possibilities for further research. It might be valuable to replicate this study with larger corpora from different faculties and compare the findings to those found at the university studied here. It is also possible to study graffiti on the walls of the faculties where only females or males study. Finally, the study recommends teachers and educators to pay more attention to students' graffiti writing.

\section{References}

Abel, E. L., \& Buckley, B. E. (1977). The handwriting on the wall: Toward a sociology and psychology of graffiti. Westport, CT: Greenwood.

Arluke, A., Kutakoff, L., \& Levin, J. (1987). Are the times changing? An analysis of gender differences in sexual graffiti. Sex Roles, 16(1-2), 1-7.

Ball, D. B. (2004). The nature and extent of desktop graffiti among U.S. college students: An exploratory study. Unpublished master thesis, Virginia Polytechnic Institute and State University, Virginia.

Barnett, M. (2006). Bathroom sex: It happens here. Retrieved August 3, 2013, from http://www.gwhatchet.com/2006/03/27/michael-barnett-bathroom-sex-it-happens-here/.

Bartholome, L. and Snyder, P. (2004). Is it philosophy or pornography? Graffiti at the Dinosaur Bar-B-Que. Journal of American Culture, 27, 86-99.

Basthomi, Y. (2007). An initial intimation of a yet banal discourse: Truck graffiti k@ta, 9(1), 34-48.

Beck, J. P. (1982). Graffiti: The Vulgar Blackboard's Wit. English Journal, 71(3), 73-74.

Blume, R. (1985). Graffiti. In T. A. van Dijk (Ed.), Discourse and literature: new approaches to the analysis of literary genres (Vol. 3, pp. 137-148): John Benjamins Publishing.

Cole, C. M. (1991). Oh wise women of the stalls... . Discourse Society:, 2(4), 401-411.

Dombrowski, Q. (2011). Walls that talk: Thematic variation in University library graffiti. Journal of the Chicago Colloquium on Digital Humanities and Computer Science, 1(3), 1-13.

Dundes, A. (1966). Here I Sit: A study of American latrinalia. Kroeber Anthropoligical Society Paper, 34, 91-105.

Dupront, A. (1987). Pèlerinages et lieuq sacrés. In D. Sacré (Ed.), Croisades et Pèlerinages: Images et langages (pp. 403). Paris: Gallimard.

Farnia, M. \& Tohidian, I. (2013). A thematic analysis of truck graffiti in Iranian context. Paper presented at the first national conference on research in teaching English, translation and linguistics (RTELT), 2-3 March, Islamic Azad university of Khorasgan, Iran.

Finders, M. J. (1997). Just girls: Hidden literacies and life in junior high: Education Resources Information Center (ERIC).

Forster, A. M., Vettese-Forster, S., \& Borland, J. (2012). Evaluating the cultural significance of historic graffiti. Structural Survey, 30(1), 43-64.

Hanauer, D. I. (2004). Silence, voice and erasure: psychological embodiment in graffiti at the site of Prime Minister Rabin's assassination. The Arts in Psychotherapy, 31(29), 35.

Haslam, N. (2012). Psychology in the bathroom: Palgrave Macmillan.

Gadsby, J. (1995). Taxonomy of analytical approaches to graffiti. Retrieved February 8, 2013, Retrieved from http://www.graffiti.org/faq/appendix.html

Grach, V. (1973). Graffiti. College English, 35(3), 285-287.

Green, J. (2003). The writing on the stall: Gender and graffiti. Journal of Language and Social Psychology, 22 (3), $282-$ 296.

Kan, J. A. W. (2006). A sociolinguistic analysis of graffiti in secondary schools: a case study of selected schools in Nyandarua. Unpublished master thesis, Egerton University, Nakuru, Kenya.

Klingman, A., Shalev, R. and Pearlman, A., 2000. Graffiti: A creative means of youth coping with collective trauma. The Arts in Psychotherapy, 27 (5), 299-208.

Koon-Hwee K. (2001). Adolescents and Graffiti. Art Education, 54(1),18-23.

Lindsay, J. (1960). The writing on the wall: An account of Pompeii in its Last Days. London: Frederick Muller Limited. 
Matthews, N., Speers, L., \& Ball, J. (2012). Bathroom banter: Sex, love, and the bathroom wall. Electronic Journal of Human Sexuality, 15(17), pp. 1-11.

McMenemy, P., \& Cornish, I. M. (1993). Gender differences in the judged acceptability of graffiti. Perceptual and Motor Skills, 77(2), 622-622.

Mueller, M. M., Moore, J. W., Doggett, R. A., \& Tingstrom, D. H. (2000). The effectiveness of contingency-specific and contingency-nonspecific prompts in controlling bathroom graffiti. Journal of Applied Behavior Analysis, 33(1), 8992.

Nwoye, O. G. (1993). Social issues on walls: Graffiti in university lavatories. Discourse \& Society, 4, 419-442.

Obeng, S. G. (2000). Speaking the unspeakable: Discursive strategies to express language attitudes in Legon (Ghana) graffiti. Research on Language and Social Interaction, 33(3), 291-319.

Otta, E. (1993). Graffiti in the 1990s: A Study of inscriptions on restroom walls. Journal of Social Psychology, 133, 589-590.

Peteet, J. (1996). The Writing on the walls: The graffiti of the intifada. Cultural Anthropology, 11 (2), 139-159.

Pietrosanti, S. (2010). Behind the tag: A journey with the graffiti writers of European walls. Amsterdam: University of Amsterdam.

Plesch, V. (2002). Graffiti and ritualization: San Sebastiano at Arborio. In J. Rollo-Koster (Ed.), Medieval and Early modern ritual: formalizaed behavior in Europe, China and Japan (pp. 127-146). Leiden, Boston, Köln: Brill.

Raymonda (2008). The sociolinguistics study of graffiti arts used in Surakarta. Unpublished master thesis, Muhammadiyah University, Surakarta, Indonesia.

Read, A. W. (1935). Lexical evidence from folk epigraphy in zuesiern Norlh America, a glossarial study of the low element in the English language. Paris: Olympic Press.

Reisner, R. (1974). Encyclopedia of graffiti. New York: Macmillan Publishing

Şad, S. N., \& Kutlu, M. (2009). A study of graffiti in teacher education. Egitim Arastirmalari-Eurasian Journal of Educational Research, 36, 39-56.

Schreer, G. E., \& Strichartz, J. M. (1997). Private restroom graffiti: An analysis of controversial social issues on two college campuses. Psychological Reports, 81, 1067-1074.

Stocker, T. L., Dutcher, L. W., Hargrove, S. M., \& Cook, E. A. (1972). Social analysis of graffiti. Journal of American Folklore, 85, 356-366.

Tanzer, H. H. (1939). The Common people of Pompeii: A study of the graffiti. Baltimore: The John Hopkins Press.

Teixeira, R. P., \& Otta, E. (1998). Restroom graffiti: a study of gender differences. Estudos de Psicologia (Natal), 3(2), 229-250.

Teixeira, R. P., Otta, E., \& Siqueira, J. D. O. (2003). Between the public and the private: sex differences in restroom graffiti from Latin and Anglo-Saxon countries. (Working Paper No 03/007) Retrieved from University De São Paulo, http://www.ead.fea.usp.br/WPapers/2003/03-007.pdf.

Tracy, S. K. (2005). The graffiti method. Australian Midwifery Journal, 18(3), 22-26.

Trahan, A. (2011). Identity and ideology: The dialogic nature of latrinalia. Internet Journal of Criminology, 1-9.

Warakomski, J. (1991). The humour of graffiti. In G. Bennett (Ed.), Spoken in Jest (pp. 279-295). Sheffield, England: Sheffield Academic Press Ltd. 